\title{
The Trichoptera diversity of Nyungwe National Park, Rwanda, with description of a new species in the family Pisuliidae
}

\author{
Leonce NGIRINSHUTI ${ }^{1}$, Simon RUKERA TABARO ${ }^{2}$ \& Kjell Arne JOHANSON ${ }^{3, *}$ \\ ${ }^{1,2}$ College of Agriculture, Animal Sciences and Veterinary Medicine, University of Rwanda, \\ P.O. Box. 210 Musanze, Rwanda. \\ ${ }^{3}$ Zoology Department, Swedish Museum of Natural History, Box 50007, 10405 Stockholm, Sweden. \\ *Corresponding author: kjell.arne.johanson@nrm.se \\ ${ }^{1}$ Email: lngirinshuti@gmail.com \\ 2Email:simon.rt@gmail.com

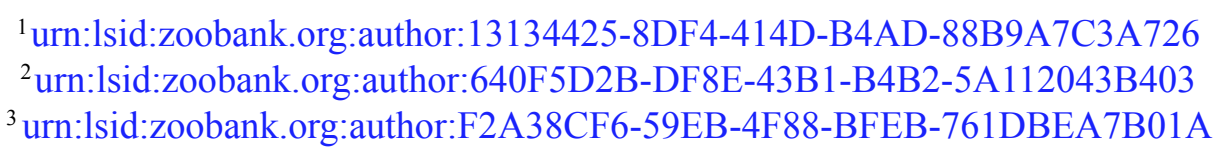

\begin{abstract}
A total of nine families of Trichoptera were identified from material collected in Malaise and light traps in the western part of Nyungwe National Park, southwestern Rwanda, late October 2018. Included in the material was an undescribed species of Pisuliidae which is described herein as Silvatares laetae Ngirinshuti \& Johanson sp. nov. The new species adds to the six Pisuliidae species previously recorded for the East African region, five endemic to Tanzania and one to Uganda. This study portrays the first results of an ongoing survey on the Trichoptera fauna of Rwanda.
\end{abstract}

Keywords. Rwanda, caddisflies, mountain streams, diversity, new species.

Ngirinshuti L., Rukera Tabaro S. \& Johanson K.A. 2019. The Trichoptera diversity of Nyungwe National Park, Rwanda, with description of a new species in the family Pisuliidae. European Journal of Taxonomy 576: 1-11. https://doi.org/10.5852/ejt.2019.576

\section{Introduction}

Trichoptera (caddisflies) are important components of freshwater communities and their species composition and population dynamics provide information on the health of aquatic ecosystems (de Moor \& Ivanov 2008; Stoyanova et al. 2014; Shimba \& Jonah 2016). The group is found in a wide range of water bodies present in all biogeographical regions except the Antarctica (Morse 2011). Their evolutionary success can be attributed to the production of silk by the larvae, which is used for construction of portable cases, filtering nets or fixed shelters (Holzenthal et al. 2007; de Moor \& Ivanov 2008; Malm et al. 2013; Holzenthal \& Calor 2017). These constructions enable them to adapt and benefit from a great variety of environmental resources (Mackay \& Wiggins 1979). They are also indispensable in the lives of the larvae for protection against predators, feeding, and stability in violent water current (Ross 1944; Marlier 1962; Malm et al. 2013). 
The knowledge of Trichoptera diversity has grown exponentially over the last hundred years (Marlier 1962). Particularly over the last 20 years, when more than one third of the known species were described (Holzenthal et al. 2007; de Moor \& Ivanov 2008; Morse 2011; Malm et al. 2013). Such great research effort can been linked with the assumption that approximately $70 \%$ of extant Trichoptera species are not known to science (de Moor \& Ivanov 2008; Holzenthal \& Calor 2017). This argument is supported by the fact that some biogeographical realms, including the Afrotropical Region, are moderately to largely understudied. The apparent knowledge gap of Trichoptera fauna in the Afrotropical Region can be associated with field identification problems. In addition, the tools and expertise for, at least, morphospecies determination are not available in many tropical countries (Godfray et al. 1999).

Specifically, the knowledge of the Trichoptera fauna in Rwanda is low, with only five species previously recorded (Johanson 1992): Hydropsyche propinqua Ulmer, 1907, Dipseudopsis capensis Walker, 1852, Lepidostoma sjoestedti (Ulmer, 1908), Ceraclea schoutedeni (Navás, 1930) and Leptocerus gracilis (Ulmer, 1912). Nevertheless, Rwanda holds freshwater systems characterized by high regional and continental impact, as well as dense networks of mountainous rivers and streams, lakes, swamps and wetlands (MINIRENA 2011). To the west of the country a chain of mountains forms the Congo-Nile Divide, which contributes important tributaries to both the Congo and Nile Rivers (Ewango 2001; Barakabuye et al. 2007).

The present study intends to provide more knowledge to the understanding of Afrotropical Trichoptera diversity by examining recently collected material in Nyungwe National Park. A Trichoptera family particularly associated with montane Afrotropical habitats is the Pisuliidae, which is endemic to the Afrotropical region (Johanson 1992; Holzenthal et al. 2007; de Moor \& Ivanov 2008). The species of this family are subject to local endemism fostered by forest isolation (Stoltze 1989). The species are grouped into two genera: Pisulia Marlier, 1943 and Silvatares Navás, 1931 (Holzenthal et al. 2007; de Moor \& Ivanov 2008). The latter genus is a senior synonym of Dyschimus Barnard, 1934 (Stoltze 1989; Prather \& Holzenthal 2002; Johanson \& Mary 2009). The new species described herein adds to six other Pisuliidae species previously recorded in the East Africa of which Silvatares chitae (Stoltze, 1989), S. crassus (Stoltze, 1989), Pisulia albimaculata Marlier, 1943, P. austrina Morse, 1974 and $P$. gitteae Stoltze, 1989 were recorded from Tanzania and Silvatares excelsus (Navás, 1931) from Uganda (Stoltze 1989; Johanson 1992).

\section{Material and methods}

\section{Study area}

Nyungwe National Park covers a tropical montane rainforest located in the southwest of Rwanda, roughly at $2^{\circ} 17^{\prime}-2^{\circ} 50^{\prime} \mathrm{S}$ and $29^{\circ} 07^{\prime}-29^{\circ} 26^{\prime} \mathrm{E}$ (Fashing et al. 2007; Gross-Camp et al. 2009). It forms a part of a mountain chain that drains into the Congo River basin to the west and the Nile River basin to the northeast (Ewango 2001; Barakabuye et al. 2007). Southward, it connects with Kibira National Park in Burundi forming one of the largest blocks of montane rainforests in Africa (Easton et al. 2011; Barakabuye et al. 2007; Gharahi Ghehi et al. 2012). With a surface area of about $1019 \mathrm{~km}^{2}$, Nyungwe National Park is the largest montane forest in Rwanda and includes Cyamudongo, a $4 \mathrm{~km}^{2}$ natural forest located $10 \mathrm{~km}$ southwest of the main forest (Easton et al. 2011; Moore et al. 2018). The national park is known for housing a high diversity of birds and primates. At least 280 bird species of which 26 are endemic to the Albertine Rift and 13 primate species, including the endangered eastern chimpanzee Pan troglodytes schweinfurthii Giglioli, 1872, exist in the area (Plumptre et al. 2006).

Nyungwe forest comprises a variety of permanent aquatic biotopes in streams, rivers, waterfalls, ponds and swamps located at altitudes between 1600-2950 m a.s.1. (Plumptre et al. 2002; Fashing 
et al. 2007; Gross-Camp et al. 2009; Gharahi Ghehi et al. 2012; Moore et al. 2018). With annual daily temperatures measured to be between 10.9 and $19.6^{\circ} \mathrm{C}$ the weather is considered as cold (Kaplin \& Moermond 1998; Moore et al. 2018). The annual rainfall averages at $1744 \mathrm{~mm}$, with the wettest periods in March to May and again in September to December. The major dry season occurs from July to August while a short dry season comes about for few weeks between December and January (Kaplin 2001).

\section{Sampling design}

Trichoptera samples were collected from 17-29 October, 2018 at localities in the south western part of Nyungwe National Park, including Cyamudongo forest (Fig. 1). Ten Malaise traps were mounted across rivers and streams over a period of 6 to 10 days. Portable light traps were operated overnight at sites not covered by Malaise traps and were placed along the stream banks. The sampling sites were selected based on a number of factors such as accessibility and uniqueness of the area based on altitude, vegetation and water volume. The collected material was stored in $80 \%$ pure alcohol (ethanol). The material was sorted and determined at the Swedish Museum of Natural History in Stockholm (SMNH), Sweden. Photographs of living individuals were taken for a few specimens before being added to alcohol in a separate vial. The specimens were sorted to family level according to the identification keys in Johanson (2010) and Marlier (1962).

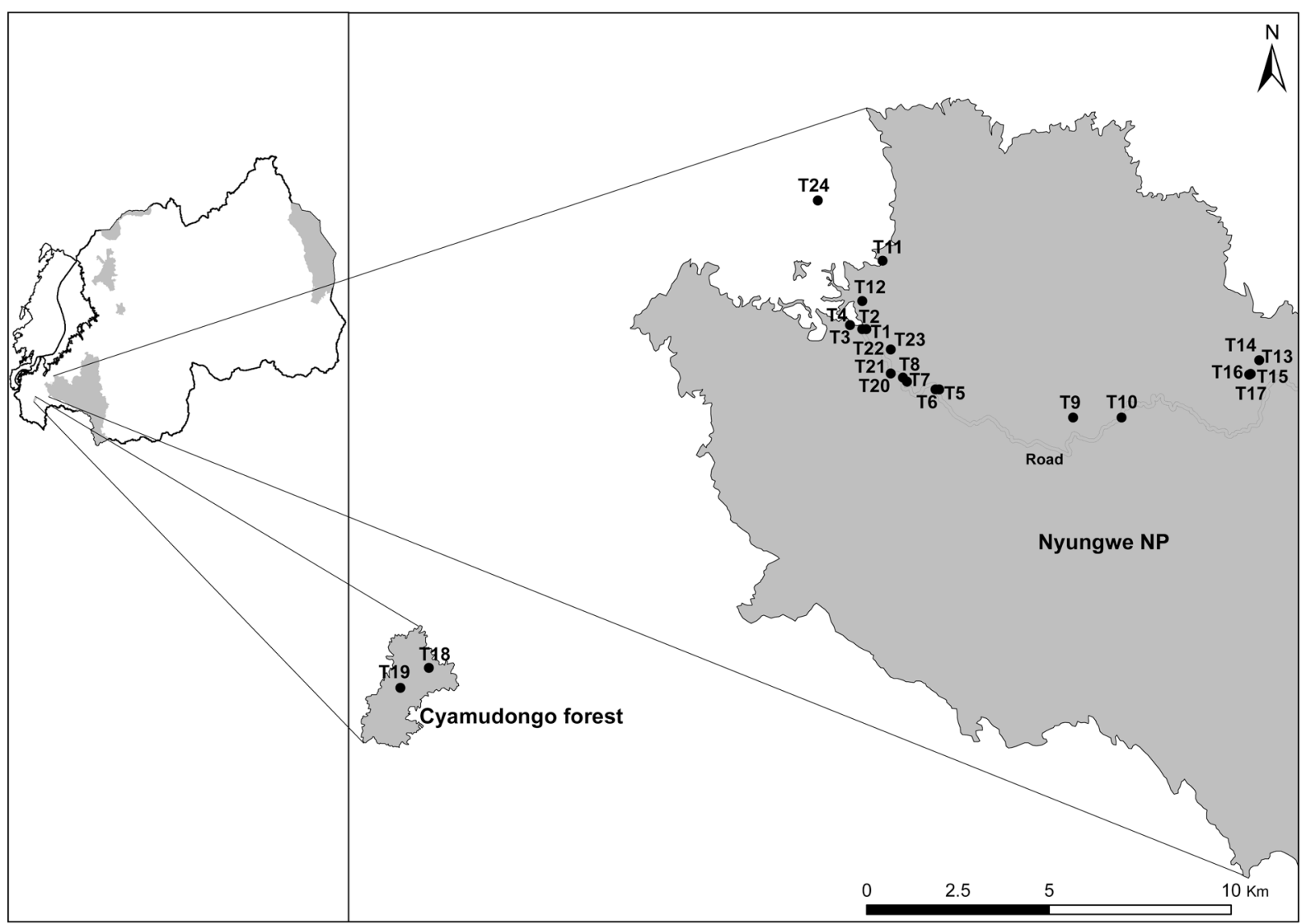

Fig. 1. Map of Rwanda (left) with indication of the position of the study area and the distribution of the sampling sites (right). 


\section{List of abbreviations}
$\mathrm{A}=$ anal vein
$\mathrm{Cu}=$ cubitus
$\mathrm{Dc}=$ discoidal cell
$\mathrm{M}=$ median vein
$\mathrm{R} 1=\operatorname{radius} 1$
$\mathrm{Rs}=$ radial sector
$\mathrm{Sc}=$ subcosta
$\mathrm{Tc}=$ thyridial cell

\section{Results}

Altogether, 543 Trichoptera specimens representing nine families were collected (Fig. 2). For specimens collected from 17 traps, the families Leptoceridae and Pschomyiidae were the most common representatives, followed by Hydropsychidae caught in 16 traps. The Pisuliidae were relatively frequent but represented only by few individuals per trap. With 127 specimens, the family Hydropsychidae was the most abundant followed by 124 individuals in the Leptoceridae and the Philopotamidae with 105 individuals. Psychomyiidae was the other family represented in high numbers while the Hydroptilidae was the least abundant family, represented only by three individuals.

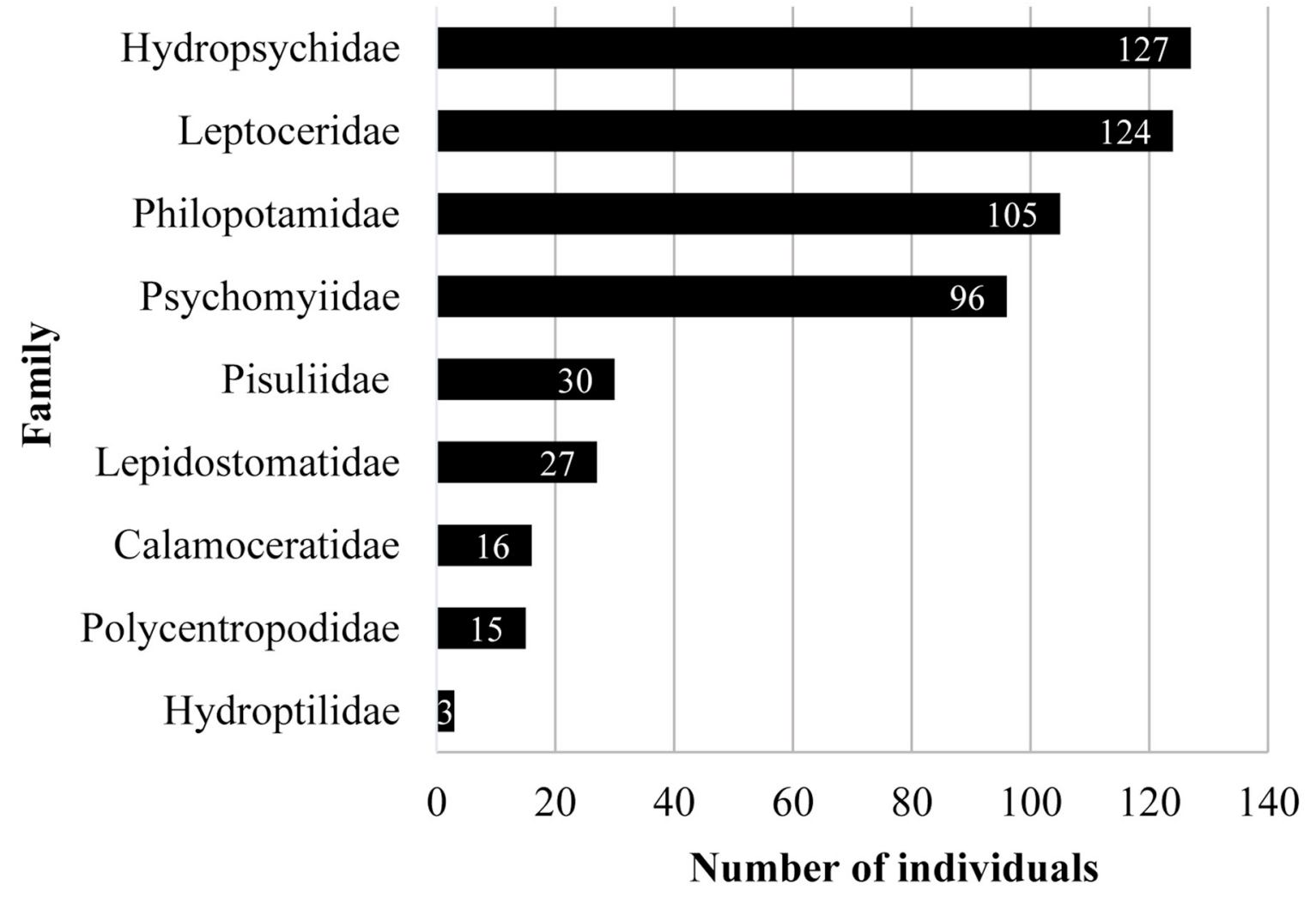

Fig. 2. Number of collected individuals per family from Malaise traps and light traps combined. 
NGIRINSHUTI L. et al., Trichoptera of Nyungwe National Park

Phylum Arthropoda von Siebold, 1848

Class Insecta Linnaeus, 1758

Order Trichoptera Kirby, 1813

Family Pisuliidae Ross, 1967

Genus Silvatares Navás, 1931

Silvatares laetae Ngirinshuti \& Johanson sp. nov. urn:1sid:zoobank.org:act:C5D1DE74-9CE5-4461-830F-211CE4BB8DBC

Figs 3-5

\section{Diagnosis}

The genitalia of Silvatares laetae Ngirinshuti \& Johanson sp. nov. resemble those of S. excelsus (Navás, 1931), particularly due to the presence of large median lobes of tergum $X$ that are curved downwards, and the inferior appendages consisting of two prominent lobes which both curve inwards in ventral view. The new species is distinguished from $S$. excelsus by the presence of a wide mouth-like incision ventrally on the tip of the median lobes of tergum X, segment IX which is produced into a pair of triangular and posteriorly pointing lateral lobes, and the presence of a pair of longer needle-like processes originating from the apex of the phallus. In addition, S. laetae Ngirinshuti \& Johanson sp. nov. has sword-shaped megasetae on tergum $\mathrm{X}$ that are absent in S. excelsus.

\section{Etymology}

Laetae, named after Dr Laetitia Nyinawamwiza in recognition of her contribution to supporting young Rwandan academicians interested in research on aquatic biota.

\section{Material examined}

Holotype

RWANDA -1 o (in alcohol); Western Province, Nyamasheke District, Nyungwe National Park, locality Gisakura, Karamba river I; $2.479^{\circ} \mathrm{S}, 29.119^{\circ} \mathrm{E} ; 1917 \mathrm{~m}$ a.s.1.; 18 Oct. 2018; K.A. Johanson, L. Ngirinshuti and P. Munyaneza leg.; light trap \#06-2018; DNA voucher LG8; NHRS.

\section{Paratype}

RWANDA - 1 o (in alcohol); Western Province, Nyamasheke District, Nyungwe National Park, Nyamirabyo River; $2.469^{\circ} \mathrm{S}, 29.108^{\circ} \mathrm{E}$; 1905 m a.s.1.; $23-26$ Oct. 2018; K.A. Johanson, L. Ngirinshuti and P. Munyaneza leg.; Malaise trap \#23-2018; DNA voucher LH9; NHRS.

\section{Description of holotype}

LENGTH AND COLOR. Forewing $10.5 \mathrm{~mm}$, hind wing $8.7 \mathrm{~mm}$. Head, thorax and abdomen yellowish-brown (Fig. 3). Antennae dark brown, almost black, slightly longer than forewings. Eyes setose, blackish. Legs brown at proximal segments, tibia and tarsus darker. Spur formula: 2:4:4.

WINGS. Forewings with greyish brown membrane densely covered with dark brownish setae, slightly darker towards apex and anterior margin. Underside with long, thick and golden setae originating from an enlarged part of $\mathrm{Cu} 2$ (Fig. 4). Forewing venation nearly similar to that of S. excelsus. Sc and R1 separate basally, connected distally by crossvein. Fork 1 originating before fork 2 , fork 4 absent, nygma present in fork 2 and in thyridial cell. Culb rudimentary, not reaching wing margin, leaving incomplete fork 5, A1 and A2 fusing near base. $\mathrm{Cu} 2$ in right angle before fusing with $\mathrm{A} 1+2$, crossvein present between $\mathrm{Cu} 2$ and $\mathrm{Cu} 1 \mathrm{~b}$. Hind wings greyish with dark setae. Long setae extending beyond the posterior margin near wing base. R1 inconspicuous, terminating in cell between Sc and Rs. Discoidal cell large, nygma present in fork 2, forks 3,4 and 5 absent. $\mathrm{Cu} 2$ apparently forming distal fork, posterior margin straight behind $\mathrm{Cu} 1$. 
AbDomen (male). Segment VII with small median tooth on sternite. Segment IX protruding into a pair of anteriorly rounded lateral lobes and undulating posterior margin; in dorsal view with deep V-shaped incision of anterior margin. Tergum $\mathrm{X}$ in lateral view large, downwardly curving along its length, with U-shaped incision at ventral part of apex; dorsal margin of apex with 3-4 sword-shaped megasetae; in dorsal view deeply divided into pair of posterad branches, division basally triangular. Pair of onesegmented inferior appendages curving mesally along their length, with two deeply incised separated branches. Upper branch with dilated apex, lower branch slender, almost thumb-shaped. Phallus stout and curved, with constriction leading to tapering tip in lateral view, equipped with pair of teeth-like structures standing erect in ventral view.

\section{Discussion}

The results of this study represent a first in a series of surveys we intend to undertake in order to describe the caddisfly diversity of Rwanda. Most natural ecosystems in the country have been under immense pressure due to human activities prior to the enforcement of effective conservation measures (Rutagarama \& Martin 2006; Barakabuye et al. 2007). In addition, most water resources outside protected areas have been degraded from intensified farming, agricultural runoffs or other human activities established near the riverbanks. Nyungwe National Park suffered almost 15\% reduction between 1958 and 1979 due to the exploitation of forest resources and encroachment (Plumptre et al. 2002). However, it remains the largest mountainous forest in the country and supports a high diversity of animals and plants as well as undisturbed water systems.

In the present study we recognize nine Trichoptera families which display an important variety of species among which several might still be undescribed. The observed richness of families clearly indicates that a larger number of species than previously known for Rwanda remains to be documented. Our findings also witness a highly species-diverse Trichoptera community in Nyungwe National Park which indicates the existence of a high number of explored niches and a specialized distribution pattern along the stream continuum, following Mackay \& Wiggins (1979).

\section{Acknowledgements}

This study was funded by the Swedish Museum of Natural History. We are grateful for the Rwanda Development Board (RDB) who offered the collection and export permits. The RDB park-based staff

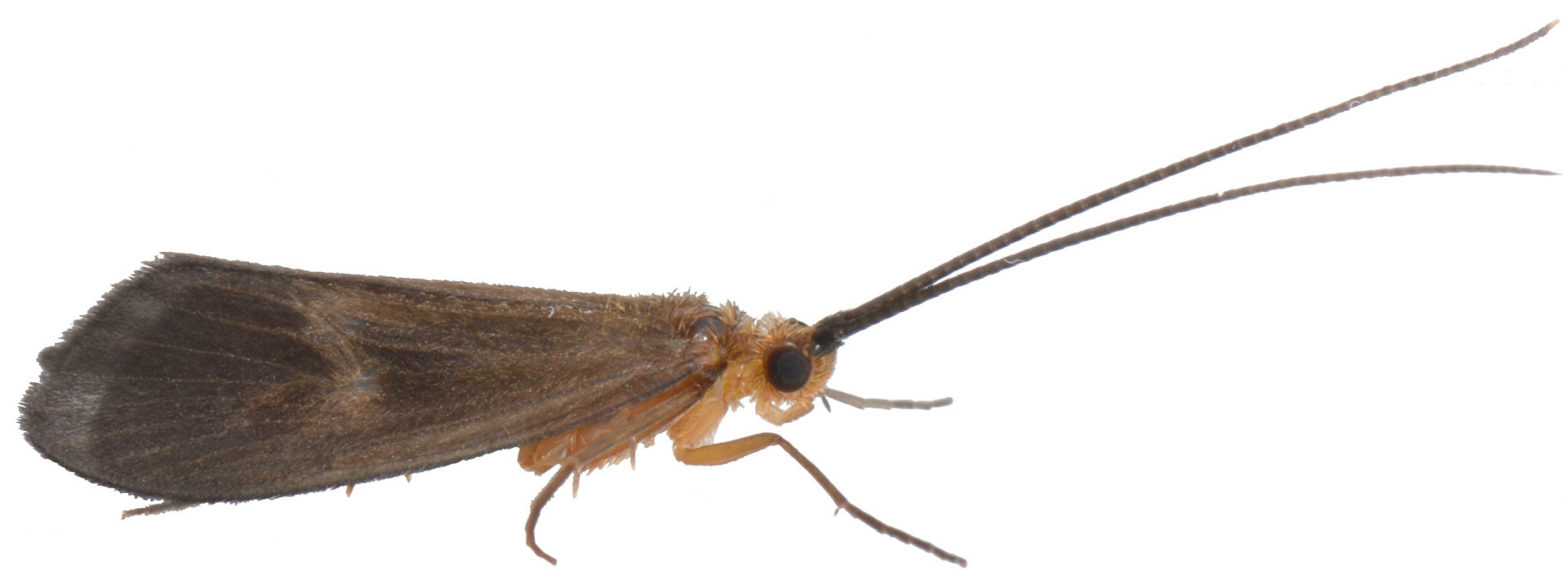

Fig. 3. Silvatares laetae Ngirinshuti \& Johanson sp. nov., O̊, holotype. 

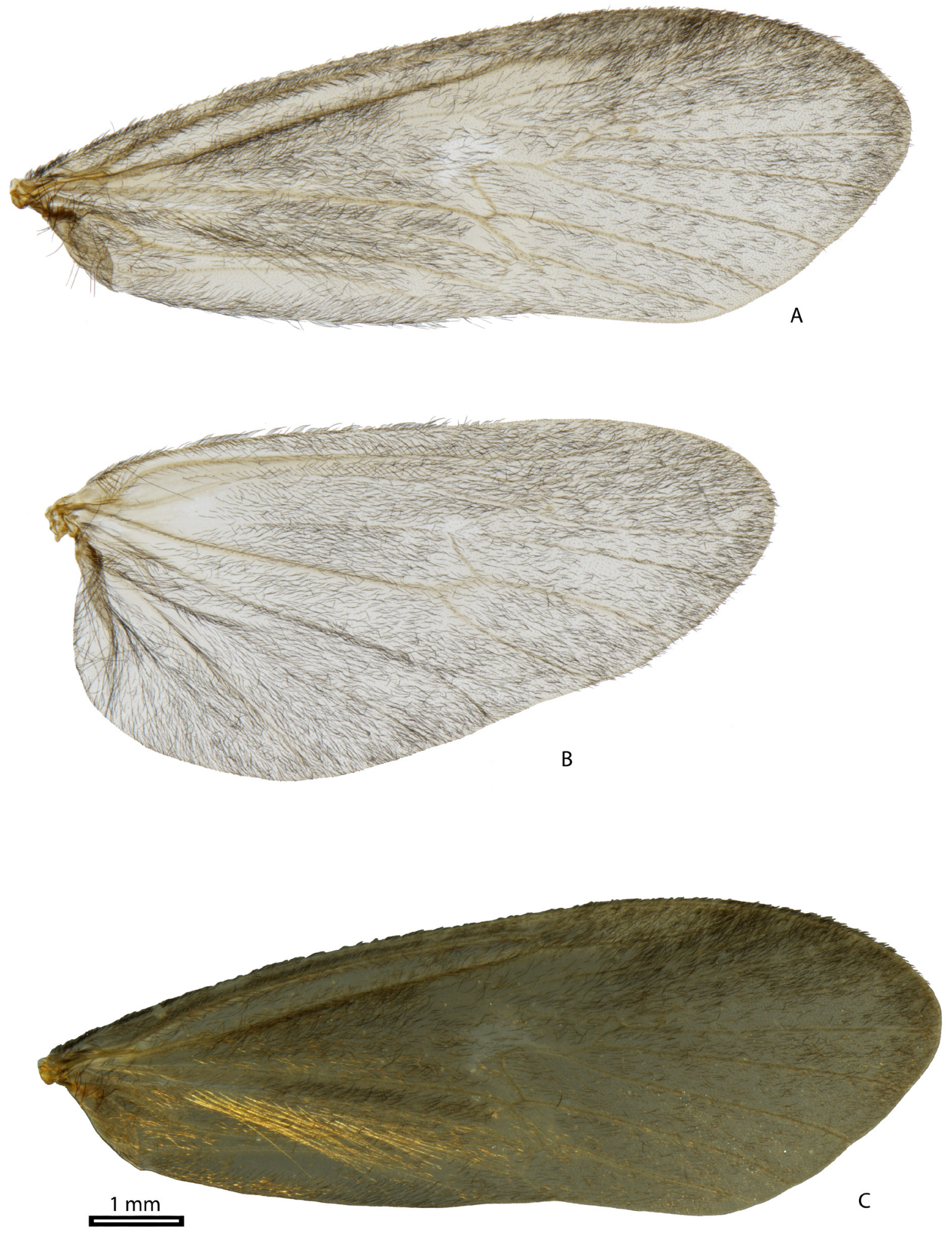

Fig. 4. Silvatares laetae Ngirinshuti \& Johanson sp. nov., Ô, holotype. A. Right forewing. B. Right hind wing. C. Right forewing, underside, showing long golden hairs. Scale bar $=1 \mathrm{~mm}$. 

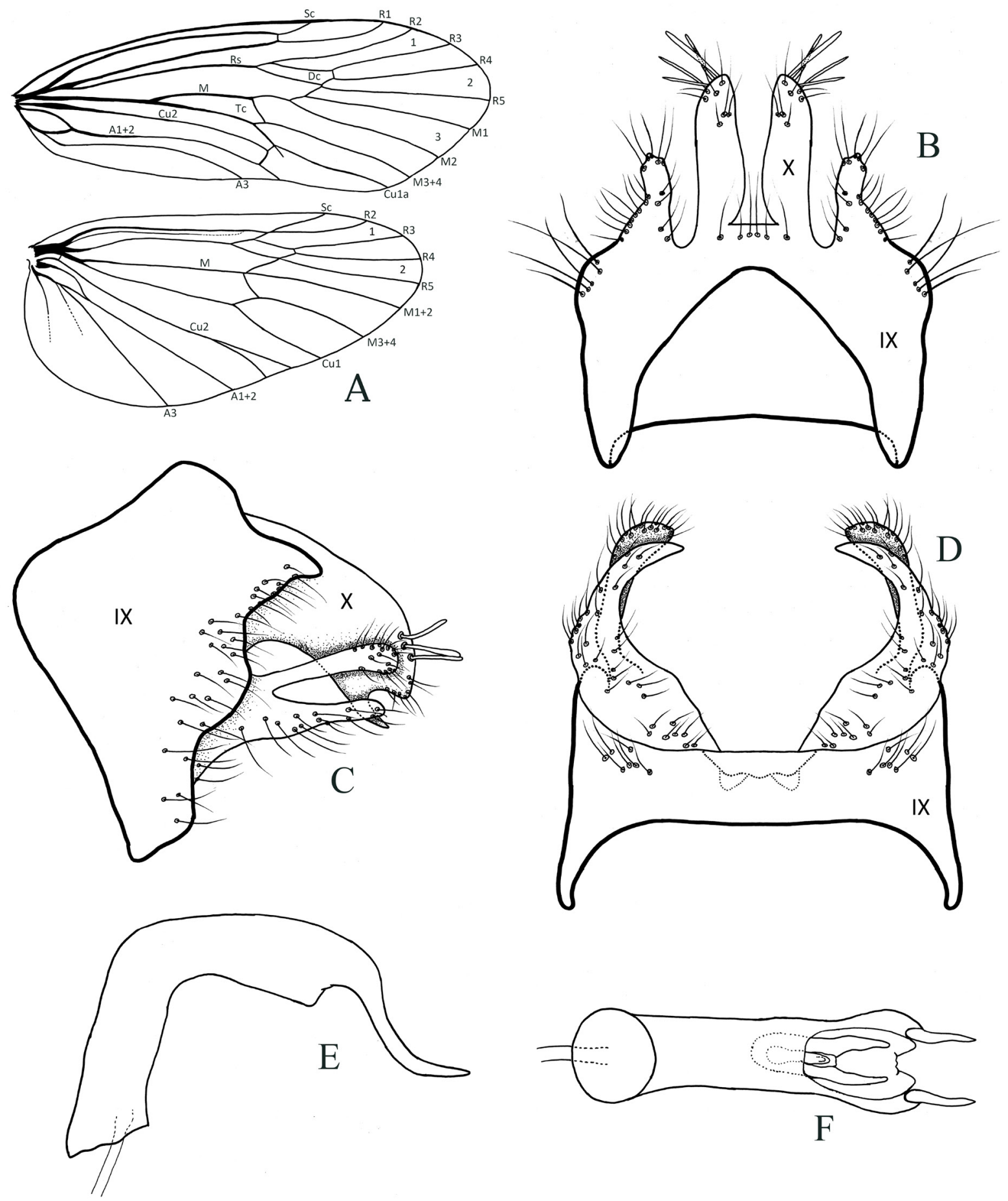

Fig. 5. Silvatares laetae Ngirinshuti \& Johanson sp. nov., ð̋, holotype. A. Right wings. B-D. Genitalia. B. Dorsal view. C. Lateral view. D. Ventral view. E-F. Phallus. E. Lateral view. F. Ventral view. 
also assisted for locating and reaching the sampling sites. We thank Dr Rodrigo Esparza-Salas for his assistance in activities of DNA lab.

\section{References}

Barakabuye N., Mulindahabi F., Plumptre A.J., Kaplin B., Munanura I., Ndagijimana D. \& Ndayiziga O. 2007. Conservation of chimpanzees in the Congo Nile Divide Forests of Rwanda and Burundi. Report to USFWS for project 98210-6-G095/GA 0282.

de Moor F.C. \& Ivanov V.D. 2008. Global diversity of caddisflies (Trichoptera: Insecta) in freshwater. Hydrobiologia 595: 393-407. https://doi.org/10.1007/s10750-007-9113-2

Easton J., Chao N., Mulindahabi F., Ntare N., Rugyerinyange L. \& Ndikubwimana I. 2011. Status and conservation of the only population of the vulnerable owl-faced monkey Cercopithecus hamlyni in Rwanda. Oryx 45 (3): 435-438. https://doi.org/10.1017/S0030605310001468

Ewango C.E.N. 2001. Flore et végétation de la forêt naturelle de Nyungwe, Rwanda. Systematics and Geography of Plants 71: 1009-1015.

Fashing P.J., Mulindahabi F., Gakima J.B., Masozera M., Mununura I., Plumptre A.J. \& Nguyen N. 2007. Activity and ranging patterns of Colobus angolensis ruwenzorii in Nyungwe forest, Rwanda: possible costs of large group size. International Journal of Primatology 28 (3): 529-550.

https://doi.org/10.1007/s10764-006-9095-3

Gharahi Ghehi N., Werner C., Cizungu Ntaboba L., Mbonigaba Muhinda J.J., Van Ranst E., ButterbachBahl K., Kiese R. \& Boeckx P. 2012. Spatial variations of nitrogen trace gas emissions from tropical mountain forests in Nyungwe, Rwanda. Biogeosciences 9: 1451-1463.

https://doi.org/10.5194/bg-9-1451-2012

Godfray H.C.J., Lewis O.T. \& Memmott J. 1999. Studying insect diversity in the tropics. Philosophical Transactions of the Royal Society of London B 354: 1811-1824. https://doi.org/10.1098/rstb.1999.0523

Gross-Camp N.D., Masozera M. \& Kaplin B.A. 2009. Chimpanzee seed dispersal quantity in a tropical montane forest of Rwanda. American Journal of Primatology 71: 901-911.

https://doi.org/10.1002/ajp.20727

Holzenthal R.W. \& Calor A.R. 2017. Catalog of the Neotropical Trichoptera (caddisflies). ZooKeys 654: 1-566. https://doi.org/10.3897/zookeys.654.9516

Holzenthal R.W., Blahnik R.J., Prather A.L. \& Kjer K.M. 2007. Order Trichoptera Kirby, 1813 (Insecta), caddisflies. Zootaxa 1668: 639-698. https://doi.org/10.11646/zootaxa.1668.1.29

Johanson K.A. 1992. A catalogue of the caddis flies of East Africa (Insecta, Trichoptera). Steenstrupia 18 (7): 113-141.

Johanson K.A. 2010. Description of sixteen new species of Trichoptera with a key to adults of known families and genera recorded in Madagascar. African Entomology 18 (2): 267-301.

https://doi.org/10.4001/003.018.0206

Johanson K.A. \& Mary N. 2009. Description of three new caddisfly species from Mayotte Island, Comoros Archipelago (Insecta: Trichoptera). Zootaxa 2089: 1-9. https://doi.org/10.11646/zootaxa.2089.1.1

Kaplin B.A. 2001. Ranging behavior of two species of guenons (Cercopithecus lhoesti and C. mitis doggetti) in the Nyungwe Forest Reserve, Rwanda. International Journal of Primatology 22 (4): 521548. https://doi.org/10.1023/A:1010716001014

Kaplin B.A. \& Moermond T.C. 1998. Variation in seed handling by two species of forest monkeys in Rwanda. American Journal of Primatology 45: 83-101.

https://doi.org/10.1002/(SICI)1098-2345(1998)45:1<83::AID-AJP7>3.0.CO;2-S 
Mackay R.J. \& Wiggins G.B. 1979. Ecological diversity in Trichoptera. Annual Review of Entomology 24: 185-208. https://doi.org/10.1146/annurev.en.24.010179.001153

Malm T., Johanson K.A. \& Wahlberg N. 2013. The evolutionary history of Trichoptera (Insecta): a case of successful adaptation to life in freshwater. Systematic Entomology 38: 459-473.

https://doi.org/10.1111/syen.12016

Marlier G. 1962. Genera des Trichoptères de 1'Afrique. Annales. Série in $8^{\circ}$. Musée royal de l'Afrique centrale. Sciences zoologiques 109: 1-263.

MINIRENA 2011. Water Resources Management Sub-Sector Strategic Plan (2011-2015). Ministry of Natural Resources, Kigali, Rwanda.

Moore J.F., Mulindahabi F., Gatorano G., Niyigaba P., Ndikubwimana I., Cipolletta C. \& Masozera M.K. 2018. Shifting through the forest: home range, movement patterns, and diet of the eastern chimpanzee (Pan troglodytes schweinfurthii) in Nyungwe National Park, Rwanda. American Journal of Primatology 80: 1-13. https://doi.org/10.1002/ajp.22897

Morse J.C. 2011. The Trichoptera World Checklist. Zoosymposia 5: 372-380.

Plumptre A.J., Masozera M., Peter J., Fashing P.J., McNeilage A., Ewango E., Kaplin A.B. \& Liengola I. 2002. Biodiversity Surveys of the Nyungwe Forest Reserve in S.W. Rwanda. Wildlife Conservation Society Working Papers 18, New York, USA.

Plumptre A.J., Davenport T.R.B., Behangana M., Kityo R., Eilu G., Ssegawa P., Ewango C., Meirte D., Kahindo C., Herremans M., Peterhans J.K., Pilgrim J.D., Wilson M., Languy M. \& Moyer D. 2006. The biodiversity of the Albertine Rift. Biological Conservation 134: 178-194.

https://doi.org/10.1016/j.biocon.2006.08.021

Prather L.P. \& Holzenthal R.W. 2002. The identity of Silvatares excelsus Navas, 1931 (Trichoptera: Pisuliidae). In: Wolfram M. (ed) Proceedings of the $10^{\text {th }}$ International Symposium on Trichoptera. Nova supplementa entomologica 15: 231-234.

Ross H.H. 1944. The caddis flies, or Trichoptera, of Illinois. Bulletin of the Illinois Natural History Survey 23 (1): 1-326.

Rutagarama E. \& Martin A. 2006. Partnerships for protected area conservation in Rwanda. The Geographical Journal 172 (4): 291-305. https://doi.org/10.1111/j.1475-4959.2006.00217.x

Shimba M.J. \& Jonah F.E. 2016. Macroinvertebrates as bioindicators of water quality in the Mkondoa River, Tanzania, in an agricultural area. African Journal of Aquatic Science 41: 453-461.

https://doi.org/10.2989/16085914.2016.1230536

Stoltze M. 1989. The afrotropical caddisfly family Pisuliidae. Systematics, zoogeography and biology (Trichoptera: Pisuliidaee). Steenstrupia 15 (1): 1-49.

Stoyanova T., Vidinova Y., Yaneva I., Tyufekchieva V., Parvanov D., Traykov I. \& Bogoev V. 2014. Ephemeroptera, Plecoptera and Trichoptera as indicators for ecological quality of the Luda Reka River, Southwest Bulgaria. Acta Zoologica Bulgarica 66 (2): 255-260.

Manuscript received: 20 July 2019

Manuscript accepted: 3 October 2019

Published on: 8 November 2019

Topic editor: Gavin Broad

Desk editor: Pepe Fernández 
Printed versions of all papers are also deposited in the libraries of the institutes that are members of the EJT consortium: Muséum national d'histoire naturelle, Paris, France; Meise Botanic Garden, Belgium; Royal Museum for Central Africa, Tervuren, Belgium; Royal Belgian Institute of Natural Sciences, Brussels, Belgium; Natural History Museum of Denmark, Copenhagen, Denmark; Naturalis Biodiversity Center, Leiden, the Netherlands; Museo Nacional de Ciencias Naturales-CSIC, Madrid, Spain; Real Jardín Botánico de Madrid CSIC, Spain; Zoological Research Museum Alexander Koenig, Bonn, Germany; National Museum, Prague, Czech Republic. 